\title{
Correction to: Southernmost record of the Giant Manta Ray Mobula birostris (Walbaum, 1792) in the Eastern Pacific
}

Bernabé Moreno ${ }^{1,2}$ and Adriana Gonzalez-Pestana ${ }^{1,3,4^{*}}$

\section{Correction to: Marine Biodiversity Records (2017)} 10:27 DOI: 10.1186/s41200-017-0130-1

In the original version of this article (Moreno \& Gonzalez-Pestana, 2017), published on 9 November 2017, the first sentence of the 'Conclusions' contains an error: the species " $M$. alfredi" has been wrongfully mentioned. The original publication of this article has been corrected.

- The sentence originally read:

"This sighting represents the southernmost record of $M$. birostris and $M$. alfredi in the southeastern Pacific $\left(12^{\circ} \mathrm{S}\right)$.

- The sentence now reads:

"This sighting represents the southernmost record of M. birostris in the southeastern Pacific $\left(12^{\circ} \mathrm{S}\right)$."

\section{Author details}

${ }^{1}$ Carrera de Biología Marina, Universidad Científica del Sur, Panamericana Sur km 19, 42 Lima, Peru. ${ }^{2}$ Naylamp Diving PADI Dive Center, Av. General

Cordova 735, 18 Lima, Peru. ${ }^{3}$ ProDelphinus, Jose Galvez 780, 18 Lima, Peru.

${ }^{4}$ James Cook University, Townsville, QLD 4811, Australia.

Received: 14 November 2017 Accepted: 27 November 2017

Published online: 08 December 2017

\section{Reference}

Moreno B, Gonzalez-Pestana A. Southernmost record of the Giant Manta Ray Mobula birostris (Walbaum, 1792) in the Eastern Pacific. Mar Biodivers Rec. 2017;10:27. https:/doi.org/10.1186/s41200-017-0130-1.

\footnotetext{
* Correspondence: adri_gonpe@hotmail.com

${ }^{1}$ Carrera de Biología Marina, Universidad Científica del Sur, Panamericana Sur km 19, 42 Lima, Peru
}

${ }^{3}$ ProDelphinus, Jose Galvez 780, 18 Lima, Peru 